\title{
Reasons for degradation and methods of repairing concrete surfaces in underground garages and multi-storey car parks
}

\author{
Andrzej Kysiak ${ }^{1}$
}

\begin{abstract}
:
The article discusses the causes of defects in concrete floors in multi-storey car parks. The most common damage to concrete floors, affecting the serviceability and durability of objects, is presented. Guidelines were formulated for designers and floor contractors to ensure the durability of concrete floor surfaces in underground garages as well as in open and closed multi-storey car parks. The article also describes the diagnostic procedure for parking facilities and the rules of conduct when choosing the right option for repairing damaged concrete floors.
\end{abstract}

\section{KEYWORDS}

multi-storey car parks; diagnostics of concrete floors; damage to concrete surfaces

\section{Introduction}

Shopping centers, hotels, office buildings and multi-family buildings, which are commonly erected in Poland, require the construction of multi-storey car parks and underground garages due to the large anticipated number of cars. After a dozen or so years of use of these facilities, due to the specific and difficult operating conditions, damage to the concrete surfaces is revealed, which reduces the comfort and safety of the parking lots. The resulting damage in the form of surface defects and cracks in the concrete floor shorten the period of trouble-free operation of parking lots.

According to the Eurocode 2 standard, defining the basic principles of designing concrete structures, the structure of parking surfaces should meet the requirements of reliability for the intended service life, without significantly reducing the usefulness and without the need to incur excessive costs for maintenance and repair works. Taking into account the standard requirements for exposure classes, the conditions of use for multi-car garages are similar to the use of roads and viaducts [1]. Concrete floors of multi-storey car parks are subject to thermal, mechanical and chemical loads, the protective coating on throughways is subject to abrasion, as a result of which the concrete is subject to increased carbonation and the action of de-icing agents used.

This article discusses the problems encountered in the design, construction and repair of damage to concrete pavements of the following types of floors:

- Type 1. Concrete floors of underground garages laid on the ground

Underground garage floors are subjected to various types of loads, the action of variable temperature and chemical aggression, and in the case of lack of or leakage of waterproofing, they are also exposed to the action of groundwater. The effects of moisture include blisters, cracks, peeling and loosening of resinous floors [1].

1 Czestochowa University of Technology, Faculty of Civil Engineering, ul. Akademicka 3, 42-218 Częstochowa, e-mail: andrzej.kysiak@pcz.pl, orcid id: 0000-0002-0842-2051 


\section{- Type 2. Concrete floors in multi-storey garages and enclosed parking lots}

In these facilities, damage to the floor is caused by the intense action of such factors such as permanent and variable loads, horizontal loads caused by vehicle braking and the negative influence of the environment, in particular such factors as: water, salts, fatty compounds, hydrocarbons and variable temperature.

- Type 3. Concrete floors in open multi-storey car parks and concrete surfaces on the roofs of parking facilities

Car park floors are exposed to atmospheric factors such as frost, snow, precipitation, and sunlight. The increase in tensile stresses in concrete is influenced by environmental impacts related to the difference in insolation of the slab due to variable shading by vehicles and thermal effects resulting from winter conditions.

\section{Basic principles of designing multi-storey car park floors}

\subsection{Underground garage floors set on the ground}

The thickness of the concrete construction slab for the surface of parking lots on the ground, depending on the loads and the foundation, is $20 \div 30 \mathrm{~cm}$. To ensure a stable foundation of the floor structure, it is extremely important to correctly assess the layout and features of the subsoil. If the floor is erected on a weak base, in which the higher ground layers have to be reinforced with geosynthetics, it can show subsidence of up to $10 \mathrm{~mm}$. This results in scratching and significant mutual displacement of the edges of the concrete floor slabs. In such situations, it is necessary to consider placing the floor construction slab on piles or gravel columns [2].

Coatings on concrete sleepers placed on foundation slabs or on the ground do not have to be flexible, but they must be vapour-permeable and, due to their anti-corrosive nature, must be a minimum $2.5 \mathrm{~mm}$. The system consists of an epoxy primer layer, a coloured epoxy resin layer with quartz sprinkling, and a coloured epoxy resin closing layer.

\subsection{Concrete floors in multi-storey garages and closed car parks}

If the concrete floor of the pavement is laid over the insulation layer and the construction board, the thickness of the concrete pavement is $10-12 \mathrm{~cm}$. For floors with a substrate in a composite slab system, the minimum thickness of the floor should be $30 \mathrm{~mm}$, and in the case of a surface placed on an insulation or a sliding layer, it should be $35 \mathrm{~mm}$ [3].

The protective resin coating must be flexible, but due to the negligible thermal effects, the requirements of the coating relate only to covering static cracks. The resinous closure coating does not have to be UV-resistant as it is not exposed to the sun. The flooring system consists of an epoxy priming resin layer, a polyurethane resin layer with quartz sprinkling, and a coloured closing resin layer (epoxy or polyurethane).

\subsection{Floors on intermediate ceilings of open car parks and car park roofs}

The surfaces of outdoor car parks are usually designed and manufactured as rough-floated concrete slabs. On intermediate ceilings in open car parks, resin floors must show the ability to cover emerging dynamic cracks because they work in the open, and must also be resistant to UV radiation. In such a case, the flooring system consists of an epoxy primer resin layer, a flexible polyurethane resin layer with quartz sprinkles and a coloured polyurethane UV-resistant sealing resin with a total thickness of min. $4 \mathrm{~mm}$.

On the roofs of multi-storey car parks, protective coatings must be able to cover dynamic cracks and be resistant to UV radiation. The flooring system consists of an epoxy primer resin layer, a layer of flexible polyurethane resin with a thickness of min. $1.5 \mathrm{~mm}$, a harder polyurethane resin wearing course with quartz sprinkles and a coloured UV resistant closing resin with a total thickness of min. $3 \mathrm{~mm}[4]$. 


\subsection{Principles of floor dilatation}

Longitudinal and transverse expansion joints should not intersect at an angle other than straight, and at the same time they should not form a grid of shifted or closely parallel contacts. The slots should not be located near the axis of the most heavily loaded traffic lanes. When choosing the length (a) and width (b) of the fields between the expansion joints, try to keep the square shape. For rectangular fields, the ratio a / b should not exceed 1.5, and the longer side should not be more than $6 \mathrm{~m}$

\section{Selected problems of designing and making floors in multi-storey car parks}

Requirements for parking floors in connection with the impact of chlorides from winter road maintenance agents (exposure classes XD 1-3) and the impact of freezing / thawing processes (exposure class XF1-4) determine the need to select an appropriate concrete class and to adopt a nominal reinforcement cover. To ensure the durability of the concrete pavement of XF4 class parking facilities, it is necessary to design a concrete mix that also meets the requirements for proper aeration and the use of cements with a limited content of siliceous ashes in order to obtain adequate frost resistance [5].

\subsection{The choice of floor concrete due to its frost resistance}

According to the PN-EN 206-1 standard, for the XF4 exposure class, it is required to use $\mathrm{C} 30 / 37$ class concrete with a maximum $\mathrm{w} / \mathrm{c}$ ratio $=0.45$ and a minimum cement content of $340 \mathrm{~kg} / \mathrm{m}^{3}$. Concretes based on CEM II cements show a much higher degree of frost resistance than concretes based on CEM III cements with the addition of blast furnace slag, which also require a longer curing period to achieve full strength [3]. It is important to use aggregate that meets the requirements of adequate frost resistance in accordance with PN-EN-1620: 2004. When using de-icing agents, the pore distribution index L should be less than $0.2 \mathrm{~mm}$, which significantly affects the concrete's resistance to cyclic freezing and thawing.

The PN-EN 206-1 standard [5] states that one of the factors increasing the frost resistance of concrete is its proper aeration, i.e. introducing evenly distributed, fine air bubbles into the concrete, the task of which is to compensate for stresses arising as a result of water freezing in the pores capillary. It is recommended to aerate the concrete within $4 \div 6 \%$.

Based on the following research [6], it was found that the air content in the concrete mix increases with the increase in fiber content. The addition of steel fibers in the amount of $22.5-30 \mathrm{~kg} / \mathrm{m}^{3}$ does not cause a significant change in the consistency of the mix, while the addition of steel fibers in the amount above $30 \mathrm{~kg} / \mathrm{m}^{3}$ changes the consistency from S4 to S3. Research carried out by the Building Research Institute [7] has shown that the frost resistance of non-aerated concrete is improved by single and fibrillated polypropylene microfibers. In concretes with fibers, a slight increase in the air content was observed (especially the content of micropores with a diameter of $<=300 \mathrm{~mm}$ ) and a favourable reduction in the pore distribution index L. Air entrainment by the fibers is not so great that it can be concluded that it is the only reason for the improvement of frost resistance. The main mechanism influencing the improvement of frost resistance to freezing / thawing is the so-called bridging of microcracks by fibers.

\subsection{Selection of reinforcement for concrete slabs of the floor}

The reinforcement of concrete pavements of outdoor parking lots is most often a reinforcement dispersed with steel or synthetic fibers, and in cases where the tensile stress level in the concrete exceeds $4 \mathrm{MPa}$, welded mesh reinforcement is designed with a relatively small diameter $(6 \div 8 \mathrm{~mm})$. These nets prevent the tendency for the corners of the slabs to rise, which is of particular importance in the case of external floor slabs with a surface thickness of less than $10 \mathrm{~cm}$ and when the surface is made in conditions of intense sunlight. 
Steel fibers (e.g. $50 / 1$ or $60 / 0.8$ ) dosed at $20 \div 30 \mathrm{~kg} / \mathrm{m}^{3}$ ) are practically no longer used due to their low corrosion resistance in an XF4 class environment. Most often, polymer fibers with a diameter of $0.03 \mathrm{~mm}$ and a length of 19.38 or $54 \mathrm{~mm}$ are used as the basic dispersed (structural) reinforcement. Their dosage is determined by calculation and usually amounts to $1.5 \div 2.5 \mathrm{~kg} / \mathrm{m}^{3}$ of concrete [3].

\section{The most common defects in the execution of parking lot floors}

\subsection{Delamination of the surface hardened layer}

The formation of a layer on the hardening concrete surface that is insufficiently bonded to the substrate and is sensitive to detachment is caused by a delay in troweling the sprinkle on the hardening and dried concrete layer. Delamination can also be local, defined by zones of increased drying out due to drafts, e.g. within open garage doors. It is difficult to decide on the optimal time to commence troweling when water is released from the concrete that is necessary to bind the hardening mix. A delay in the performance of troweling may also result from the failure to adjust the working parameters of the concrete mix to the weather conditions as well as from the failure to adjust the scope of the flooring works to the capabilities of the employees performing the work.

\subsection{Incorrect conditions for laying the concrete mix and defective concrete care}

A very common weakness of floors that appears immediately after laying is a network of irregular surface cracks and internal micro-cracks. This defect is mainly due to the use of incorrect technology and inadequate quality concrete materials and the lack of the required maintenance. The mesh of shrinkage cracks may be the result of the lack of anti-shrinkage reinforcement or its inappropriate location in the concrete slab, too large a distance between expansion joints, and an incorrect selection or quality of concrete components.

After laying the concrete mix, in the care phase, along with the troweling and hardening phase, due to the fact that they are made in the open, there is the risk of drying out the surface due to sunlight or wind, resulting in peeling of the upper layer. A threat to the proper maturation process of concrete is also rainfall in the period of the first 6 hours after the concrete mix has been laid until it is rubbed off and hardened. Therefore, the floor surface should be covered with foil or fleece. It is also possible to spray the surface with impregnation that prevents evaporation of water from the concrete, which significantly reduces the shrinkage of concrete in the plastic phase [3].

In winter, the concrete mix may be spread in a way that results in the degradation of the parking lot surface, resulting in dusting, crushing and easy separation of aggregate from the surface. Freezing can be caused both by the incorporation of cooled concrete, in which the binding heat is insufficient for proper bonding of the concrete mix, and the cooling of plastic, bonding concrete in a poorly protected place of incorporation.

\subsection{Defects in the execution of expansion joints and improper reinforcement}

In the event of revealing strong cracks in the floor with an irregular arrangement, the cause of this defect is the insufficient number or improper arrangement of expansion joints, overloading the floor, insufficient stiffness of the concrete slab or insufficient bearing capacity of the subfloor or subsoil. Cracks with a regular direction and spacing result from the restriction of the consolidation of the concrete mix by the reinforcement. In order to eliminate this cause, mixes with a higher degree of compaction and reinforcement bars of smaller diameter should be used.

Strong cracks in the floor may also result from making the floor construction board on an improperly prepared concrete base with a PVC film as a sliding layer. The surface of the base 
concrete is not always even and free of the remains of the base concreting, and moreover, it is very often cracked to the extent that it defragments the base into separate slabs. Failure to prepare this surface (e.g. by milling in places of unevenness and strengthening in places of strong cracks) results in the creation of resistance to movement of the floor construction plate in the phase of shrinkage growth.

\section{Diagnostic procedure for floors in multi-storey car parks}

The condition for the development of an appropriate repair method for a damaged floor is to carry out a thorough and professional assessment of the technical condition of the floor together with the subsoil. The full diagnostic procedure of parking facilities should include an assessment of the condition of the structure on the basis of a review of the design documentation and construction documents, as well as the results of field tests. Depending on the situation, the following tests should be performed [8]:

- Visual assessment and inventory of damage to the floor. Carrying out an inventory of damages, especially in the case of high intensity of their occurrence, allows to clearly determine the causes of damage.

- The testing of the load-bearing capacity of the floor includes the assessment of the cooperation of the panels within the cracks and joints and the testing of the support of the panels. The measurement is performed with an FWD deflection meter with a plate of $300 \mathrm{~mm}$ in diameter and a dynamic load of $50 \mathrm{KN}$. The assessment of the support conditions of the floor within the cracks and joints enables the determination of the condition of the substructure and the subsoil under the slab joint and determination of the proper cooperation between the layers.

- Structure continuity testing with the GRSP Penetrator Radar designed to test the thickness and type of structural layers of industrial floors, road surfaces and subsoil.

- In order to determine the condition of the concrete in the floor structure, boreholes for structure samples are made and concrete samples are tested for compressive strength. Additionally, tests of the subsurface concrete layer of the floor are carried out for tear-off using the pull-off method.

- Testing of reinforcing steel in the direction of determining the diameter of bars and their position in the structure (spacing, thickness of the concrete cover). This information can be obtained on the basis of the results of scanning the reinforcement or using, for example, radiological methods.

- determination of the range of the carbonation front, testing the content of chlorides in concrete.

\section{Methods of repairing typical floor damages}

In the case of cracks resulting from exceeding the permissible thermal stresses and tensile stresses as a result of shrinkage, additional antispasmodic dilatations are made in the concrete, expansion joints are repaired, and the resulting cracks are merged by injection of epoxy resins.

Microcracks should be merged by surface saturation with primers, the places of the detached floor should be cut or milled. Remove loosened and deformed fragments of the floor, and after applying the bonding layer, make a new floor. The application of thin-layer masses does not work, and it is recommended to use $4 \div 5 \mathrm{~cm}$ thick inserts or to cut out entire damaged parts of the surface and replace with new ones. In places of visible faults and grooving of the floor, make an injection of microcement in loose, uncompressed places, repair the edges of the floor fields and install dowel rods.

Cracks in the area of the expansion joint should be joined with epoxy injections, the edges of the expansion joints should be repaired and the expansion joints should be filled with appropriate expansion compounds adapted to the operating conditions. 


\section{Conclusion}

A necessary condition for the implementation of concrete floors is a thorough concrete quality control carried out by a laboratory independent of the concrete supplier, which has the necessary equipment to perform frost resistance and aeration tests.

The design and execution of multi-storey car park floors require great care and attention to the works performed by all participants in the construction process. Both the designer and the contractor are responsible for the final result, in the event of defects, it is extremely difficult to determine the causes of damage and responsibility for them.

\section{References}

[1] Kulas T., Uszkodzenia i naprawa podłóg w garażach wielostanowiskowych, Materiały Budowlane 2010, 9, 457, 26-27, 34

[2] Ryżyński W., Projektowanie i realizacja betonowych posadzek przemysłowych, Materiały Budowlane 2008, 9, 433, 14-15, 67.

[3] Ryżyński W., Projektowanie, realizacja i eksploatacja betonowych nawierzchni parkingów zewnętrznych, Materiały Budowlane 2010, 9, 457, 29-31.

[4] Zając G., Posadzki w parkingach wielopoziomowych i garażach podziemnych, Materiały Budowlane 2008, 9, 433.

[5] Dohojda M., Szulc J., Sztuka K., Diagnostyka żelbetowych elementów płytowych w obiektach parkingowych, Materiały Budowlane 2015, 11, 519, 50-52.

[6] Chajec A., Wpływ włókien stalowych na właściwości mieszanek betonowych do wykonywania posadzek, Materiały Budowlane 2019, 6, 562, 70-71.

[7] Michalik A., Szaj P., Wpływ mikrowłókien polimerowych na mrozoodporność betonu, Materiały Budowlane $2015,11,519,30-32$.

[8] Graczyk M., Diagnostyka posadzek przemysłowych, Materiały Budowlane 2008, 9, 433, 10-11.

\section{Przyczyny degradacji i metody naprawy nawierzchni betonowych w garażach podziemnych i parkingach wielopoziomowych}

\section{STRESZCZENIE:}

Przedyskutowano przyczyny powstawania wad nawierzchni posadzek betonowych w wielokondygnacyjnych parkingach samochodowych. Przedstawiono najczęściej występujące uszkodzenia posadzek betonowych mające wpływ na użytkowanie i trwałość obiektów. Sformułowano wytyczne dla projektantów i wykonawców posadzek zapewniające trwałość betonu nawierzchni posadzek w garażach podziemnych oraz otwartych i zamkniętych parkingach wielopoziomowych. Artykuł zawiera ponadto opis procedury diagnostycznej obiektów parkingowych i zasady postępowania podczas wyboru właściwej opcji naprawy uszkodzonych posadzek betonowych.

\section{SŁOWA KLUCZOWE:}

wielopoziomowe parkingi; diagnostyka posadzek betonowych; uszkodzenia posadzek betonowych 